\title{
History of benthic colonisation beneath the Amery Ice Shelf, East Antarctica
}

\author{
Alexandra L. Post ${ }^{1, *}$, Mark A. Hemer ${ }^{1}$, Philip E. O'Brien ${ }^{1}$, Donna Roberts ${ }^{2}$, \\ Mike Craven ${ }^{3}$ \\ ${ }^{1}$ Marine and Coastal Environment Group, Geoscience Australia, GPO Box 378, Canberra, ACT 2601, Australia \\ ${ }^{2}$ Institute of Antarctic and Southern Ocean Studies, University of Tasmania, Private Bag 77, Hobart, Tasmania 7001, Australia \\ ${ }^{3}$ Australian Antarctic Division and Antarctic Climate and Ecosystems Co-operative Research Centre, Private Bag 80, Hobart, \\ Tasmania 7001, Australia
}

\begin{abstract}
This study presents compelling evidence for a diverse and abundant seabed community that developed over the course of the Holocene beneath the Amery Ice Shelf, East Antarctica. Fossil analysis of a $47 \mathrm{~cm}$ long sediment core revealed a rich modern fauna dominated by filter feeders (sponges and bryozoans). The down-core assemblage indicated a succession in the colonisation of this site. The lower portion of the core (before $~ 9600 \mathrm{yr}$ BP) was completely devoid of preserved fauna. The first colonisers (at $\sim 10200 \mathrm{yr} \mathrm{BP}$ ) were mobile benthic organisms. Their occurrence was matched by the first appearance of planktonic taxa, indicating a retreat of the ice shelf following the last glaciation to within sufficient distance to advect planktonic particles via bottom currents. The benthic infauna and filter feeders emerged during the peak abundance of the planktonic organisms, indicating their dependence on the food supply sourced from the open shelf waters of Prydz Bay. Understanding patterns of species succession in this environment has important implications for determining the potential significance of future ice shelf collapse.
\end{abstract}

KEY WORDS: Ice shelf $\cdot$ Succession $\cdot$ Holocene $\cdot$ Benthic fauna $\cdot$ Microfossil

\section{INTRODUCTION}

The Antarctic shelf fauna have been strongly influenced by the expansion and retreat of the Antarctic ice sheets on glacial-interglacial time scales (Clarke \& Crame 1992, Thatje et al. 2005). The expansion of the ice sheets across the continental shelf during glacial periods largely eradicated the available shelf habitats and evidence suggests that these shelf fauna may have migrated to either the Antarctic slope or the deep sea (e.g. Zinsmeister \& Feldmann 1984, Brandt, 1991, Brey et al. 1996). In some regions, however, shelf fauna may have found refugia during glacial periods beneath floating ice shelves in regions where grounded ice did not advance to the edge of the continental shelf. Geological evidence suggests that during the last glaciation the ice sheets did not completely ground to the shelf edge in the western Ross Sea (Licht et al. 1996, Shipp et al. 1999), Prydz Bay (Domack et al. 1998, O'Brien et al. 1999) or George Vth Land (Beaman \& Harris 2003). However, the viability of benthic communities in these sub-ice shelf environments is not well known from current studies.

Floating ice shelves typically have been considered as unlikely habitats for benthic organisms. Samples from beneath the Ross Ice Shelf reveal a paucity of benthic biota with no living infauna (Lipps et al. 1979). Some evidence exists for a diversity and abundance of fauna living beneath the McMurdo Ice Shelf (Kellogg et al. 1977), but it is not possible to fully determine the nature and composition of the modern communities from these surface ice shelf sediments no longer preserved in situ. Video footage recorded beneath the Amery Ice Shelf at Site AM01b, provides the first evi- 
dence for a diverse benthic assemblage dominated by suspension feeders in a setting far $(\sim 100 \mathrm{~km})$ from open water (Riddle et al. 2007).

Determining the nature of modern sub-ice shelf communities and their sensitivity to change is crucial for assessing potential ecosystem impacts of global warming, particularly given that these environments represent $36 \%$ of the Antarctic continental shelf (Clarke \& Johnston 2003). Ice shelves are dynamic systems, as shown by the recent disintegration of the Larsen A and B ice shelves, and may be particularly sensitive to the impacts of future global warming. Holocene records from beneath floating ice shelves can provide baseline information to better assess the long term dynamics of these systems and the development of sub-ice shelf communities and their response to environmental change since the last glaciation. Such information has been lacking to date. Sediment cores collected from beneath the Ross (Clough \& Hansen 1979 ) and the Novolazarevskiy (Kolobov \& Savatyugin 1983) ice shelves have not yielded any Holocene sediment, reflecting the low penetration of open shelf water currents to these sites.

The recolonisation history in Antarctic open shelf environments has also been difficult to assess due to a paucity of Holocene fossil records from these shelf environments. Calcium carbonate organisms are typically not well preserved on the Antarctic shelf since the bottom waters are generally undersaturated in calcium carbonate (e.g. Kennett 1966, Anderson 1975, Ishman \& Domack 1994, Igarashi et al. 2001). The rate and pattern of colonisation of these shelf environments since the last glaciation is, therefore, not known.

Some insight into the response of the Antarctic shelf fauna to change can be gained from modern studies of recovery following iceberg disturbance. Such studies indicated that recolonisation times are relatively slow in the Antarctic environment with a recovery time of 250 to $500 \mathrm{yr}$ (Gutt \& Starmans 2001), compared with less than $50 \mathrm{yr}$ in Arctic communities (Conlan et al. 1998). The progression through each successional stage is consistent on different parts of the Antarctic Shelf (Gerdes et al. 2003, Gutt \& Piepenburg 2003) with similar patterns also observed in Arctic environments (Gutt et al. 1996, Conlan et al. 1998, Conlan \& Kvitek 2005). These studies may provide insight into recolonisation patterns on longer timescales in polar environments.

In this study, we present a history of benthic recolonisation beneath the Amery Ice Shelf based on the fossil content in a Holocene sediment core (AM01b). This study adds to our understanding of the processes that have shaped the colonisation of this sub-ice shelf community since glacial times and the processes that presently maintain it. Understanding the bio-physical processes that have sustained and continue to sustain this community is important for assessing the potential impacts of ice shelf collapse on these habitats.

\section{REGIONAL SETTING AND HISTORY}

\section{Regional setting}

The Amery Ice Shelf is the third largest ice shelf in Antarctica and is the terminus of the Lambert Glacier-Amery Ice Shelf ice drainage system, which drains about $16 \%$ of the grounded East Antarctic Ice Sheet (Allison 1979, Fricker et al. 2000). The Amery Ice Shelf discharges into Prydz Bay, a re-entrant in the East Antarctic coastline between $69^{\circ} \mathrm{E}$ and $80^{\circ} \mathrm{E}$. The morphology of the sea floor in Prydz Bay and beneath the Amery Ice Shelf shows a typical depth profile for a glaciated margin with the deepest areas $(\sim 1200 \mathrm{~m})$ inshore, near the front of the Amery Ice Shelf in the Amery Depression, shoaling to 100 to $200 \mathrm{~m}$ on the outer shelf (Fig. 1). Greater depths (>2200 m, Fricker et al. 2001) are found near the present ice shelf grounding zone well inland $(550 \mathrm{~km}$ ) from Prydz Bay (Fricker et al. 2002). The Amery Depression is linked to the shelf edge by the Prydz Channel, which occupies the western part of the bay and has depths from $700 \mathrm{~m}$ below sea level at its inshore end to about $500 \mathrm{~m}$ below sea level at the shelf edge (Fig. 1).

\section{Circulation patterns}

Early studies of marine circulation beneath ice shelves concluded that currents are formed by a baroclinic circulation cell developed in the cavity under the ice shelf (MacAyeal 1985, Hellmer \& Obers 1989, Jacobs et al. 1992, Hellmer \& Jacobs 1992). Melting at and just downstream from the grounding line produces a buoyant freshwater plume that rises along the base of the ice shelf, entraining seawater with it. Seawater flows in along the seabed towards the grounding line to replace the entrained seawater outflow. Subsequent studies of the Amery Ice Shelf have confirmed that such a process is active, but that other oceanographic factors produce barotropic circulation cells so that the pattern of inflow, outflow and refreezing of meltwater is more complex (Fig. 1; Hemer et al. in press).

The presence of marine ice at the base of the ice shelf upstream from Site AM01b suggests that the site is a region of net basal freeze with barotropic outflow beneath the ice shelf (Hemer et al. in press). Current measurements collected along the front of the ice shelf indicate that there are 2 circulation cells at the seafloor (Hemer 2003; Fig. 1). There is a large inflow on the 

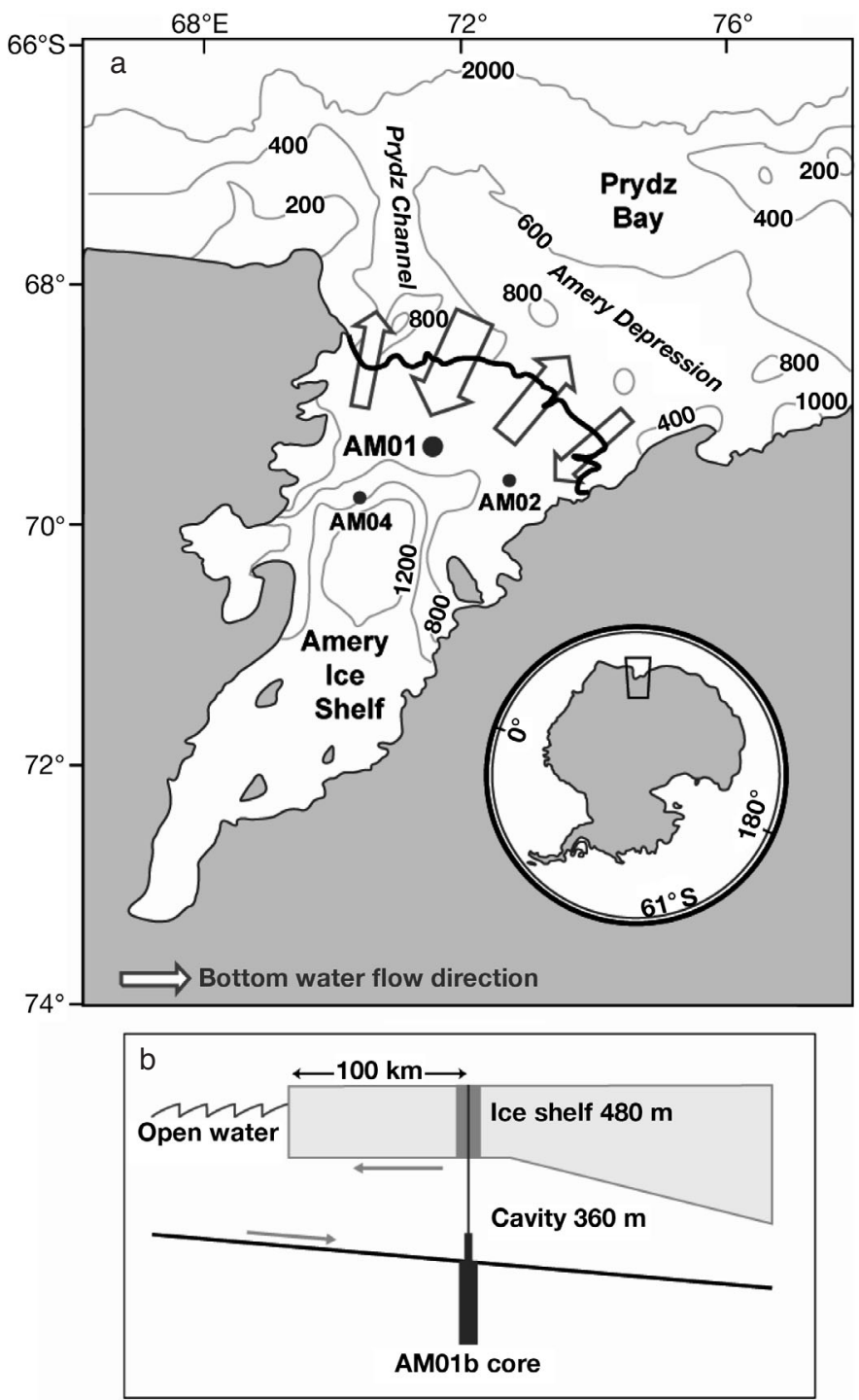

Fig. 1. (a) Bottom current directions in the Amery Ice Shelf region in relation to the AM01b sediment core site. Contour lines are marked in metres below sea level. Bottom water circulation patterns are based on current moorings deployed along the front of the ice shelf (Hemer 2003). (b) Schematic cross-section of AM01b site from open water (left) towards the ice shelf grounding line (right). The bottom shelf water inflow and the outflow below the base of the ice sheet are shown beneath the ice shelf

eastern side of the cavity with return outflow occurring slightly to the west, and another circulation cell on the western side of the cavity. The large inflow that occurs at depth in the region of the AM01b site is countered by outflow immediately beneath the ice shelf base. Conductivity, temperature and depth (CTD) casts taken through the bore hole at Site AM01 indicate a bottom salinity $(\sim 34.57)$ and temperature $\left(\sim-1.9^{\circ} \mathrm{C}\right)$ (Rosenberg et al. 2002), which is consistent with the presence of low salinity shelf water.

\section{Glacial history}

The Amery Ice Shelf has repeatedly advanced and retreated onto the shelf since the early Oligocene epoch (Hambrey 1991), with the last extreme ice advance occurring during the mid to late Pleistocene (O'Brien et al. 2007). During the Last Glacial Maximum, grounding line features indicated that the Lambert Glacier probably advanced into central Prydz Bay (Domack et al. 1998), although the absence of subglacial features in Prydz Channel suggests that this area may have remained free of grounded ice $\left(\mathrm{O}^{\prime}\right.$ Brien et al. 1999). Sites along the eastern side of Prydz Bay indicate a minimum age for retreat of the grounding line at 10600 to 10900 yr BP (Domack et al. 1991, O'Brien \& Leitchenkov, 1997), while the onset of marine sedimentation at Site AM02 beneath the Amery Ice Sheet occurred at 15000 yr BP (Hemer \& Harris 2003). This pattern has been interpreted as indicating rapid retreat of the grounding line along the axis of Prydz Channel (Hemer \& Harris 2003). The later retreat of the ice sheet from sites within eastern Prydz Bay may result from differences in the drainage times for the coastal glacial systems compared with the Amery-Lambert Glacier system (Hemer 2003).

\section{MATERIALS AND METHODS}

During the austral summer of 2003-2004 a hot water drill was used to create a $400 \mathrm{~mm}$ access hole through the $480 \mathrm{~m}$ thick Amery Ice Shelf (Craven et al. 2004). A purpose built slim line gravity corer, $12 \mathrm{~cm}$ in diameter, was lowered through the access hole to collect a $47 \mathrm{~cm}$ long sediment core at Site AM01b $\left(69^{\circ} 26^{\prime} \mathrm{S}, 71^{\circ} 27^{\prime} \mathrm{E}\right)$ beneath the Amery Ice Shelf (for further details see Hemer et al. in press). This site is located $\sim 100 \mathrm{~km}$ south of the current ice edge and is $840 \mathrm{~m}$ below the ice shelf surface. Accelerator mass spectrometer (AMS) ${ }^{14} \mathrm{C}$ dates from bulk organic matter and a brachiopod shell indicate that the surface of the core represents recent deposition (Hemer et al. in press) with no obvious evidence for surface disturbance. A bulk organic matter sample at $18-19 \mathrm{~cm}$ yielded a date of $13529 \pm 50 \mathrm{BP}$ (9596 \pm 50 BP corrected). Dates towards the base of the core could not be constrained due to the abundance of older reworked organic matter (Hemer et al. in press).

The fossil content preserved in 11 subsamples down the core was assessed from the $>150 \mu \mathrm{m}$ size fraction. The biota were identified to phylum or class level and counted as numbers per gram of sediment. Eleven categories were recognised, viz. Porifera, Bryozoa, Polychaeta (Annelida), Ostracoda (Crustacea), benthic and planktonic Foraminifera, Pteropoda (Mollusca), Gastropoda (Mollusca), Brachiopoda, Echinodermata and 
Radiolaria. The bryozoans, polychaetes and sponges were present as fragments so could not be counted as individuals. These organisms were therefore weighed and are reported as a percentage of the total sample weight. The echinoderms were also present only as fragments, but due to their very low abundance in the core these fragments could not be weighed accurately. The echinoderms, along with all the other organisms listed above, are reported as the number of individuals per gram (ind. $\mathrm{g}^{-1}$ ) of sediment. The main mineral constituents in the $>150 \mu \mathrm{m}$ fraction were also recorded. In this study we also draw on the diatom results reported in Hemer et al. (in press).

\section{RESULTS}

Microscopic analysis of the lower samples (28 to $46 \mathrm{~cm}$ ) in the AM01b core indicates that these sediments are almost devoid of fauna, dominated instead by siliciclastic sediments. At $46 \mathrm{~cm}$ a trace number of planktonic foraminifera ( 2 ind. $\mathrm{g}^{-1}$ ) are present; while at $28 \mathrm{~cm}$ traces of sponge spicules (1 spicule, Appendix I, Fig. 2) exist. Trace numbers of diatoms also are present throughout this lower section, but no other fauna are found in the $>150 \mu \mathrm{m}$ fraction.

At $21 \mathrm{~cm}$ the first significant faunal remains appear, with benthic foraminifera most abundant (110 ind. $\mathrm{g}^{-1}$ ) in this interval, followed by ostracods (75 valves $\mathrm{g}^{-1}$ ) and planktonic foraminifera (75 ind. $\mathrm{g}^{-1}$ ) (Fig. 2). Sponge spicules have a very low abundance $(0.0003 \%$ by weight) at this depth; a few unidentified organisms also occur (9 ind. $\mathrm{g}^{-1}$ ). Diversity and abundance increases upwards dramatically within the upper $17 \mathrm{~cm}$, with all 11 categories of biota present. The quartz content decreases significantly in this interval from 21 to $17 \mathrm{~cm}$. Benthic foraminifera and ostracods are the dominant fauna at $17 \mathrm{~cm}$ with abundances of 1330 ind. $\mathrm{g}^{-1}$ and 1100 valves $\mathrm{g}^{-1}$, respectively. Abundances of these 2 classes, along with planktonic foraminifera, gradually decrease upward through the rest of the core. Polychaete tubes, sponge spicules and bryozoan pieces are the dominant fauna throughout the upper $13 \mathrm{~cm}$ of the core, with abundance increasing gradually towards the surface. The upper $5 \mathrm{~cm}$ is dominated by mats of bryozoa ( $64.2 \%$ by weight), sponge spicules $(4.5 \%$ by weight) and polychaete tubes $(6 \%$ by weight). Pteropods, radiolaria, gastropods, fragments of echinoderms and brachiopods are also present with low abundances $\left(<120\right.$ ind. $\left.\mathrm{g}^{-1}\right)$ throughout the upper $17 \mathrm{~cm}$ of the core. Possible drop stones of 3 to $5 \mathrm{~cm}$ in diameter are recorded at 13 and $8 \mathrm{~cm}$.

The fauna can be summarised based on their life habitat strategies as filter feeders (sponges and bryozoans), mobile deposit feeders (benthic foraminifera, ostracods, echinoderms, gastropods) and plank-

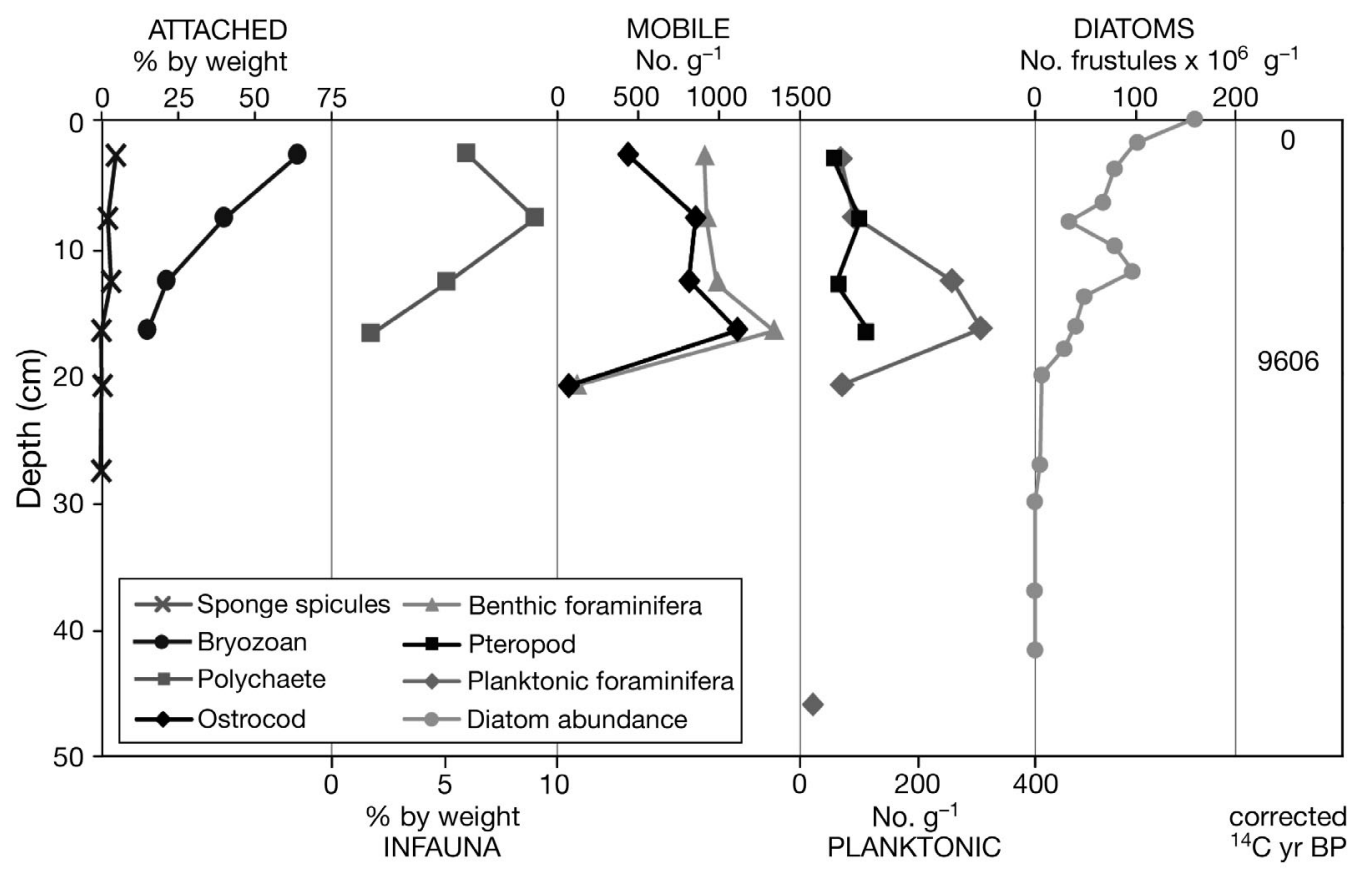

Fig. 2. Abundance of microfossils within the AM01b sediment core. The peak abundance in mobile organisms matches that of the planktonic foraminifera, indicating that the bottom currents that brought in the planktonic foraminifera assisted in the dispersal of the mobile organisms. The following decline in both of these groups may indicate the continued influence of current flow in distributing these mobile organisms; however, the high abundance and exceptional preservation of the mobile organisms in the core suggests that most of their production is in situ. The possible processes driving their decline are discussed fully in the text 
tonic organisms (planktonic foraminifera, pteropods and radiolarians). Polychaetes have various feeding strategies from sessile to mobile deposit feeders depending on the particular species, so are considered only as infauna. This grouping of organisms indicates that mobile organisms are the first group to appear in the core (at $21 \mathrm{~cm}$ ), corresponding with the first appearance of the planktonic organisms (Fig. 2). Filter feeders and polychaetes are not recorded until the following interval $(17 \mathrm{~cm})$ and steadily increase in abundance upwards through the core. The mobile organisms peak in abundance in this interval $(17 \mathrm{~cm})$, and then decline gradually towards the top of the core along with the planktonic organisms. The polychaetes increase in abundance to $8 \mathrm{~cm}$, and then decline towards the surface.

\section{DISCUSSION}

\section{Stages and rate of succession}

The first benthic fauna to colonise the AM01b site are mobile deposit feeders, which appear in the sediment core from 10 200 yr BP. These fauna most likely represent the first stage of recolonisation of this site following the retreat of the ice sheet at the end of the last glaciation, with a retreat of grounded ice from the nearby AM02 site at 15132 yr BP (Hemer \& Harris 2003). This pattern of recolonisation (dominated first by the mobile organisms) is consistent with that of Antarctic (Gerdes et al. 2003, Gutt \& Piepenburg 2003) and Arctic (Gutt et al. 1996, Conlan et al. 1998, Conlan \& Kvitek 2005) shelf communities following iceberg scouring and that predicted following glacial retreat in the Arctic (Syvitski et al. 1989), although the particular organisms described from the AM01b core differ from those previous studies. The recovery of benthic communities following iceberg disturbance has been described in 3 stages of succession (Gutt \& Piepenburg 2003). The first stage is dominated by mobile deposit feeders, which become progressively less abundant through the second and final successional stages. The second stage is associated with high abundances of polychaetes and the final successional stage is dominated by filter feeders such as bryozoans and sponges. These patterns of recolonisation for the suspension feeders, polychaetes and mobile deposit feeders are similar to the style of recolonisation that occurs at Site AM01b beneath the Amery Ice Shelf.

Rates of succession in this sub-ice shelf setting appear to be considerably slower than on the open shelf. The composition of the near surface samples, dominated by bryozoans with sponges, is consistent with communities identified on the open shelf as being in a late stage of succession or having reached maturity (Gutt \& Piepenburg 2003). Given the recent development of this 'climax' community at the AM01b site, a rate of colonisation can be implied, with the transition from the first stage of succession to this more mature community occurring over a period of up to $9350 \mathrm{yr}$ (Table 1). Mature or seemingly undisturbed communities on the open shelf, by contrast, are a minimum of only 500 yr old based on the age of the sponges. The slow rates of succession beneath this ice shelf may reflect the long dispersal distance to the site as well as the low food supply due to the absence of in situ primary production in the water column.

Based on the dating of marine sediments in Core AM02, which is located $50 \mathrm{~km}$ to the east of AM01b, grounded ice retreated from the site at $\sim 15132 \mathrm{yr}$ BP (Hemer \& Harris 2003). The onset of recolonisation at $\sim 10600$ yr BP at Site AM01b implies that the mobile colonisers took $\sim 5000$ yr to reach the site. However, the timing of recolonisation fits in well with the broader picture of deglaciation in the Prydz Bay region. Retreat of the grounding line at sites along the eastern side of Prydz Bay indicate a minimum age of 10600 to 10900 yr (Domack et al. 1991, O'Brien \& Leitchenkov 1997), with the retreat occurring more rapidly along the axis of Prydz Channel, which is consistent with the relatively old retreat dates obtained from the AM02

Table 1. Pattern of succession in the AM01b sediment core

\begin{tabular}{|c|c|c|c|}
\hline & Year BP & Indicator & Interpretation \\
\hline & 15132 & Appearance of marine sediments in AM02 & Retreat of grounded ice (Hemer \& Harris 2003) \\
\hline Stage 1 & $\begin{array}{c}10644 \\
8567\end{array}$ & $\begin{array}{l}\text { First appearance of mobile deposit feeders in AM01b } \\
\text { Peak abundance in mobile deposit feeders and } \\
\text { planktonic foraminifera }\end{array}$ & $\begin{array}{l}\text { Onset of recolonisation } \\
\text { Peak in bottom current strength facilitates } \\
\text { dispersal of mobile organisms }\end{array}$ \\
\hline Stage 2 & 3894 & $\begin{array}{l}\text { Peak abundance in polychaetes and declining mobile } \\
\text { deposit feeders }\end{array}$ & $\begin{array}{l}\text { Increasing dominance of polychaetes causes } \\
\text { decreased feeding success for deposit feeders }\end{array}$ \\
\hline Stage 3 & 1298 & Filter feeders increasingly dominant & $\begin{array}{l}\text { Consistent supply of advected food particles } \\
\text { and oxygen via inflowing bottom currents } \\
\text { sustains filter feeder community }\end{array}$ \\
\hline
\end{tabular}




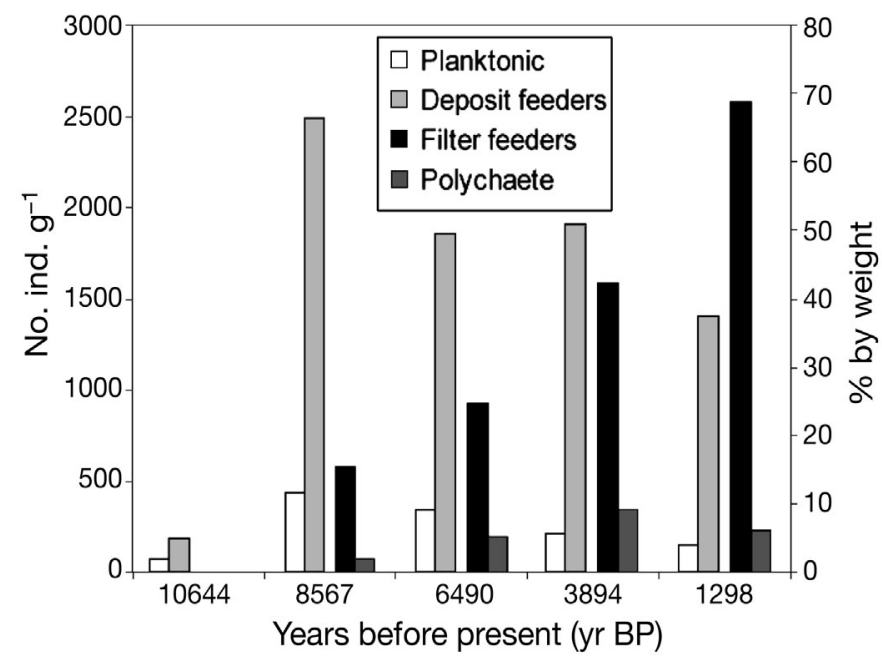

Fig. 3. Succession of filter feeders, mobile deposit feeders, infauna and planktonic organisms in the AM01b sediment core. Ages in the core are approximated based on the radio carbon dates in Hemer et al. (in press)

core. The localised retreat of the grounding line along Prydz Channel may have restricted the penetration of shelf currents and, hence, the dispersal of benthic organisms to the AM01b and AM02 sites. The larger ice shelf areas around the eastern Prydz Bay area would have also restricted the area of open water available for primary productivity, further reducing the sustainability of benthic communities beneath the ice shelf. The low food input to the sub-ice shelf environment in this interval is supported by the presence of a few modern diatoms in the lower part of the AM01b core (Hemer et al. in press; Fig. 2). The presence of the modern diatoms indicates that the ice sheet was not grounded over the site during this interval; however, their low numbers implies there was little penetration of marine water to the site.

\section{Processes driving succession}

The initial colonisation of the AM01b site by mobile deposit feeders (primarily benthic foraminifera and ostracods) and their sudden increase in abundance is matched by the appearance and increase in the planktonic foraminifera Neogloboquadrina pachyderma (sinistra) (Table 1). Radiolaria, pteropods and diatoms also reach high abundances at the time of peak abundance seen in the mobile deposit feeders ( 8570 yr BP). Since the lifecycle of these planktonic organisms is not viable in the extremely low light levels that exist beneath this ice shelf, their presence indicates advection of open shelf waters to the site (Hemer et al. in press). These currents probably assist in the dispersal of the benthic foraminifera and ostracods to this site as well as provide pelagic food sources and oxygen required to sustain the benthic community, particularly for the filter feeders, which first appear at the time of maximum planktonic foraminifera abundance (see also Kellogg \& Kellogg 1988).

Following their peak abundance at $\sim 8570$ yr BP, the mobile deposit feeders exhibit a steady decline towards the top of the core. The decline of these organisms is matched by the increasing abundances of polychaetes and bryozoans (Table 1). Some tube dwelling polychaetes select the smallest, most organic-rich particles from the surface sediments to construct their burrows (Aller \& Yingst 1978), thereby reducing food availability for other organisms. At very high densities tube dwelling polychaetes may also restrict the movement of burrowing organisms by binding the sediments (Fager 1964, Woodin 1974). The density of polychaetes through time can not be fully determined from the AM01b core record, but such mechanisms may have contributed to the decline in mobile deposit feeders associated with increasing polychaete abundance from $~ 8570$ yr BP.

Dominance by deposit feeders in benthic communities has been inferred to cause unfavourable conditions for recruitment and survival of suspension feeders due to the turbid conditions created during feeding by the deposit feeders (Rhoads \& Young 1970, Dayton \& Oliver 1980). Seafloor turbidity may be particularly detrimental to the recruitment of juvenile suspension feeders since the settling particles may smother larvae and clog filtering structures. Although this hypothesis is not accepted in many situations (see Snelgrove \& Butman 1994), there are some instances where it is likely that these interactions do occur (Snelgrove 1999). We propose that in areas of low food supply, such as beneath the Antarctic Ice Shelves, high bottom turbidity could be particularly detrimental to the growth and feeding ability of juvenile suspension feeders where this process dominates the supply of particles to the water column. The decline in deposit feeders at $\sim 8570$ yr BP at the AM01b site may have reduced the turbidity of food-poor sediments, thereby favouring increasing abundances of suspension feeders.

The decreasing inorganic flux associated with retreat of the grounding line beneath the Amery Ice Shelf following the last glacial period (Hemer et al. in press) may have also reduced the stress on suspension feeders. In Arctic fjords high sedimentation rates of inorganic matter associated with high glacial activity are thought to effectively impede the settlement and growth of suspension feeding organisms (Syvitski et al. 1989, Wlodarska-Kowalczuk \& Pearson 2004).

The increasing abundance of the suspension feeders from 8570 yr BP also matches an increase in the number of diatoms preserved in the core. Diatoms arrive at the site via bottom current advection, and their in- 
crease at this time indicates an enhanced advected food supply due to either increasing bottom current strength beneath the ice shelf or higher productivity in the open shelf waters associated with decreasing ice volumes. The association between the influx of diatoms and suspension feeder production in this study reflects the importance of the horizontal advected food supply for suspension feeder growth (Dayton \& Oliver 1980, Wildish \& Kristmanson 1997, Gutt 2000).

\section{IMPLICATIONS AND CONCLUSIONS}

The results from the AM01b core highlight the crucial importance of the advected food supply in forming and sustaining these sub-ice shelf communities. Areas of ice shelves where outflow of bottom waters occur support very little fauna, with only rare occurrences of filter feeders in outflow areas in the Ross Sea and McMurdo Sound ice shelves (Dayton \& Oliver 1977). Areas which are more distal from open water sites also are populated much more sparsely. Samples collected from beneath the Ross Ice Shelf, $400 \mathrm{~km}$ from open water, contain no recent microfauna (Ronan et al. 1978, Webb et al. 1979). At Site AM04, located $\sim 170 \mathrm{~km}$ south of the edge of the Amery Ice Shelf $(70 \mathrm{~km}$ farther south from AM01b), marine ice is accreted at the base of the ice shelf implying bottom water inflow may exist at this site. Video evidence from this site indicates the presence of a mobile polychaete, jellyfish and krill, but no suspension feeders were imaged in contrast to the live sponges and bryozoans observed at the AM01b site (Craven et al. 2006). The sediment core from the AM04 site also contains no preserved microfossils. This evidence suggests that although a food supply to this site exists, it is insufficient to support the same diversity of organisms, particularly of filter feeders, as is seen at Site AM01b $70 \mathrm{~km}$ closer to the ice edge.

Understanding the processes which shape and maintain these sub-ice shelf communities provides a background against which the effects of ice shelf collapse on the sub-ice shelf biota may be predicted. This study indicates that the ecosystem beneath the Amery Ice Shelf has developed in tandem with changes in the organic supply rate, with the first colonisation of the site following the last period of glaciation occurring at the commencement of shelf water advection. Suspension feeders show a considerable increase in abundance in concert with the increasing flux of diatoms. Changes to this advected food supply would have significant implications for this sub-ice shelf community.

Modern patterns of sedimentation in open water areas of Prydz Bay provide some insight into the changes that may occur if the Amery Ice Shelf collapsed. Holocene sedimentation rates in Prydz Bay are $0.011 \mathrm{~cm} \mathrm{yr}^{-1}$ with the sediments dominated by diatomaceous ooze (Taylor \& McMinn 2002). In the Holocene section of Core AM01b, by contrast, the sedimentation rate is just $0.0019 \mathrm{~cm} \mathrm{yr}^{-1}$ (Hemer et al. in press). The large difference in sedimentation rates between the open water and sub-ice shelf setting therefore indicates that the phytoplankton supply to the sediment is an order of magnitude lower in the subice shelf environment than in open water. Domack et al. (2005) reported that within 3 yr of the collapse of the Larsen B Ice Shelf, the chemosynthetic ecosystem was undergoing significant change due to the influx of phytoplankton detritus, which favours colonisation by benthic grazers and higher-level predators. The change to more open water conditions at sites currently beneath the Amery Ice Shelf would similarly provide a significant increase in the phytoplankton detritus reaching the seafloor, which is analogous to the present situation in Prydz Bay. It is likely that this would cause significant changes to the present sub-ice shelf ecosystem and, in particular, would favour colonisation by benthic grazers.

Acknowledgements. The authors thank Dr A. Ruddell (previously of the Antarctic Co-operative Research Centre) and H. Tassel (Geoscience Australia) for provision of sub-ice shelf geometry data, T. Watson, C. Thun and A. McLachlan (all of Geoscience Australia) for laboratory analysis, and personnel who have assisted with the AMISOR program, both in the field and with technical input in Australia. We also thank J. Gutt and I. Zondervan (both of the Alfred Wegener Institute) for insightful discussions, and P. Harris, K. Glenn (Geoscience Australia) and 2 anonymous reviewers for their review of an earlier version of this manuscript. The sub-ice shelf sediments were first collected as part of the AMISOR geoscience program under an ASAC grant (ASAC 1210) to Dr P. Harris (Geoscience Australia) as part of the larger AMISOR program (ASAC 1164). A.L.P., M.A.H. and P.E.O. publish with the permission of the Chief Executive Officer, Geoscience Australia.

\section{LITERATURE CITED}

Allison I (1979) The mass budget of the Lambert Glacier drainage basin, Antarctica. J Glaciol 22:223-235

Aller RC, Yingst JY (1978) Biogeochemistry of tube-dwellings: a study of the sedimentary polychaete Amphitrite ornate (Leidy). J Mar Res 36:201-254

Anderson JB (1975) Ecology and distribution of foraminifera in the Weddell Sea of Antarctica. Micropaleontology 1: 69-96

Beaman RJ, Harris PT (2005) Bioregionalization of the George V Shelf, East Antarctica. Cont Shelf Res 25:1657-1691

Brey T, Dahm C, Gorney M, Klages M, Stiller M, Arntz WE (1996) Do Antarctic benthic invertebrates show an extended level of eurybathy? Antarct Sci 8:3-6

Brandt WE (1991) Colonization of the Antarctic shelf by the isopod (Crustacea, Malacostraca). Ber Polarforsch 91: $1-240$

Clarke A, Crame JA (1992) The Southern Ocean benthic fauna and climate change: a historical perspective. Phil Trans R Soc Lond B Biol Sci 338:299-309 
Clarke A, Johnston NM (2003) Antarctic marine benthic diversity. Oceanogr Mar Biol Annu Rev 41:47-114

Clough JW, Hansen BL (1979) The Ross Ice Shelf project. Nature 203:433-434

Conlan KE, Kvitek RG (2005) Recolonization of soft-sediment ice scours on an exposed Arctic coast. Mar Ecol Prog Ser 286:21-42

Conlan KE, Lenihan HS, Kvitek RG, Oliver JS (1998) Ice scour disturbance to benthic communities in the Canadian High Arctic. Mar Ecol Prog Ser 166:1-16

Craven M, Allison I, Brand R, Elchiekh A, Hunter J, Hemer M, Donoghue S (2004) Initial borehole results from the Amery Ice Shelf hot-water drilling project. Ann Glaciol 39: 531-539

Craven M, Rasch D, Brand R, Drinkell A, Donoghue S, Pedro $\mathrm{J}$ (2006) Borehole imagery within and beneath the Amery Ice Shelf. SCAR XXIX/COMNAP XVIII Conf Proc, Hobart, Tasmania

Dayton PK, Oliver JS (1977) Antarctic soft-bottom benthos in oligotrophic and eutrophic environments. Science 197: $55-58$

Dayton PK, Oliver JS (1980) An evaluation of experimental analyses of population and community patterns in benthic marine environments. In: Tenore KR, Coull BC (eds) Marine benthic dynamics. University of South Carolina Press, Columbia, SC, p 93-120

Domack EW, Jull AJT, Nakao S (1991) Advance of East Antarctic outlet glaciers during the Hypsithermal: implications for the volume state of the Antarctic ice sheet under global warming. Geology 19:1059-1062

Domack E, O'Brien PE, Harris PT, Taylor F, Quilty PG, De Santis L, Raker B (1998) Late Quaternary sediment facies in Prydz Bay, East Antarctica and their relationship to glacial advance onto the continental shelf. Antarct Sci 10: 236-246

Domack E, Ishman S, Leventer A, Sylva S, Willmott V, Huber B (2005) A chemotrophic ecosystem found beneath Antarctic Ice Shelf. EOS Trans Am Geophys Union 86: 269-276

Fager EW (1964) Marine sediments: effects of a tube-building polychaete. Science 143:356-359

Fricker HA, Warner RC, Allison I (2000) Mass balance of the Lambert Glacier-Amery Ice Shelf system, East Antarctica: a comparison of computed balance fluxes and measured fluxes. J Glaciol 46:561-570

Fricker HA, Popov S, Allison I, Young N (2001) Distribution of marine ice beneath the Amery Ice Shelf. Geophys Res Lett 28:2241-2244

Fricker HA, Allison I, Craven M, Hyland G and 6 others (2002) Redefinition of the Amery Ice Shelf, East Antarctica, grounding zone. J Geophys Res 107, doi:10.1029/ 2001JB000383

Gerdes D, Hillbig B, Monteil A (2003) Impact of iceberg scouring on macrobenthic communities in the highAntarctic Weddell Sea. Polar Biol 26:295-301

Gutt J (2000) Some 'driving forces' structuring communities of the sublittoral Antarctic macrobenthos. Antarct Sci 12: 297-313

Gutt J, Piepenburg D (2003) Scale-dependent impact on diversity of Antarctic benthos caused by grounding of icebergs. Mar Ecol Prog Ser 253:77-83

Gutt J, Starmans A (2001) Quantification of iceberg impact and benthic recolonisation patterns in the Weddell Sea (Antarctica). Polar Biol 24:615-619

Gutt J, Starmans A, Dieckmann G (1996) Impact of iceberg scouring on polar benthic habitats. Mar Ecol Prog Ser 137: 311-316
Hambrey MJ (1991) Structure and dynamics of the LambertGlacier-Amery Ice Shelf system: Implications for the origin of Prydz Bay sediments. In: Barron J, Larsen B et al. (eds) Proc Ocean Drilling Progr Sci Results 119:61-76

Hellmer HH, Jacobs SS (1992) Ocean interactions with the base of the Amery Ice Shelf. Antarct J Geophys Res 97(C): 20305-20371

Hellmer HH, Olbers DJ (1989) A two-dimensional model for the thermohaline circulation under an ice shelf. Antarct Sci 1:325-336

Hemer MA (2003) The oceanographic influence of sedimentation on the continental shelf: a numerical comparison between tropical and Antarctic environments. PhD thesis, University of Tasmania, Hobart, Tasmania

Hemer MA, Harris PT (2003) Sediment core from beneath the Amery Ice Shelf, East Antarctica, suggests mid-Holocene ice shelf retreat. Geology 31:127-130

Hemer MA, O'Brien PE, Post AL, Craven M, Truswell EM, Roberts D, Harris PT (in press) Sedimentological signatures of the sub-Amery Ice Shelf circulation. Antarct Sci

Igarashi A, Numanami H, Tsuchiya T, Fukuchi M (2001) Bathymetric distribution of fossil foraminifera within marine sediment cores from the eastern part of LützowHolm Bay, East Antarctica, and its paleoceanographic implications. Mar Micropaleontol 42:125-162

Ishman SE, Domack EW (1994) Oceanographic controls on benthic foraminifers from the Bellingshausen margin of the Antarctic Peninsula. Mar Micropaleontol 24:119-155

Jacobs SS, Hellmer HH, Doake CSM, Jenkins A, Frolich RM (1992) Melting of ice shelves and the mass balance of Antarctica. J Glaciol 130:375-387

Kellogg TB, Kellogg DE (1988) Antarctic cryogenic sediments: biotic and inorganic facies of ice shelf and marinebased ice sheet environments. Palaeogeogr Palaeocl 67: $51-74$

Kellogg TB, Stuvier M, Kellogg DE, Denton GH (1977) Marine microfossils on the McMurdo Ice Shelf. Antarct J US 12: $82-83$

Kennett JP (1966) Foraminiferal evidence of a shallow calcium carbonate solution boundary, Ross Sea, Antarctica. Science 153:191-193

Kolobov DD, Savatyugin LM (1983) Bottom sediments under the Novolazarevskiy Ice Shelf. Polar Geogr Geol 6: $267-271$

Licht KJ, Jenning AE, Andrews JT, Williams KM (1996) Chronology of late Wisconsin ice retreat from the western Ross Sea, Antarctica. Geology 24:223-226

Lipps JH, Ronan TE Jr, DeLaca TE (1979) Life below the Ross Ice Shelf, Antarctica. Nature 203:447-449

MacAyeal DR (1985) Evolution of tidally triggered meltwater plumes below ice shelves. In: Jacobs SS (ed) Oceanology of the Antarctic Continental Shelf. Am Geophys Union Antarct Res Ser 43:133-143

O'Brien PE, Leitchenkov G (1997) Deglaciation of Prydz Bay, East Antarctica, based on echo sounding and topographic features. In: Barker PF, Cooper AK (eds) Geology Seismic Stratigraphy of the Antarctic Margin, Vol 2. Antarct Res Ser 71:109-125

O'Brien PE, De Santis L, Harris PT, Domack E, Quilty PG (1999) Ice shelf grounding zone features of western Prydz Bay, Antarctica: sedimentary processes from seismic and sidescan images. Antarct Sci 11:78-91

O'Brien PE, Goodwin I, Forsberg CF, Cooper AK, Whitehead J (2007) Late Neogene ice drainage changes in Prydz Bay, East Antarctica and the interaction of the Antarctic ice sheet evolution and climate. Palaeogeogr Palaeocl 245: $390-410$ 
Rhoads DC, Young, DK (1970) The influence of deposit-feeding organisms on sediment stability and community trophic structure. J Mar Res 28:150-178

Riddle MJ, Craven M, Goldsworthy PM, Carsey F (2007) A diverse benthic assemblage $100 \mathrm{~km}$ from open water under the Amery Ice Shelf, Antarctica. Paleoceanography 22, PA1204, doi:10.1029/2006PA001327

Ronan TE Jr, Lipps JH, DeLaca TE (1978) Sediments and life under the Ross Ice Shelf (J-9), Antarctica. Antarct J US 13: 141-142

Rosenberg M, Bindoff N, Curran C, Helmond I and 5 others (2002) Amery Ice Shelf experiment (AMISOR), marine science cruises AU0106 and AU0207-oceanographic field measurements and analysis. Antarct CRC Res Rep No. 30, Hobart, Australia

Shipp SS, Anderson JB, Domack EW (1999) Late Pleistocene-Holocene retreat of the West Antarctic ice-sheet system in the Ross Sea: part 1-geophysical results. Geol Soc Am Bull 111:1486-1516

Snelgrove PVR (1999) Getting to the bottom of marine biodiversity: sedimentary habitats. BioScience 49:129-138

Snelgrove PVR, Butman CA (1994) Animal-sediment relationships revisited: cause versus effect. Oceanogr Mar Biol Annu Rev 32:111-177
Syvitski JPM, Farrow GE, Atkinson RJA, Moore PG, Andrews JT (1989) Baffin Island fjord macrobenthos: bottom communities and environmental significance. Arctic 42:232-247

Taylor F, McMinn A (2002) Late Quaternary diatom assemblages from Prydz Bay, Eastern Antarctica. Quat Res 57: $151-161$

Thatje S, Hillenbrand CD, Larter R (2005) On the origin of Antarctic marine benthic community structure. Trends Ecol Evol 20:534-540

Webb PN, Ronan TE Jr, Lipps JH, DeLaca TE (1979) Miocene glaciomarine sediments from beneath the southern Ross Ice Shelf, Antarctica. Science 203:435-437

Wildish D, Kristmanson D (1997) Benthic suspension feeders and flow. Cambridge University Press, Cambridge

Wlodarska-Kowalszuk M, Pearson TH (2004) Soft-bottom macrobenthic faunal associations and factors affecting species distribution in an Arctic glacial fjord (Kongsfjord, Spitsbergen). Polar Biol 27:155-167

Woodin SA (1974) Polychaete abundance patterns in a marine soft-sediment environment: the importance of biological interactions. Ecol Monogr 44:171-187

Zinmeister WJ, Feldmann RM (1984) Cenozoic high-latitude heterochroneity of southern hemisphere marine faunas. Science 224:281-283

Appendix 1. Abundances of benthic biota preserved in sediment. Bryozoans, sponge spicules and polychaete tubes are shown as weight $(\mathrm{g})$ per gram of sediment, while other values are as number of individuals per gram of sediment

\begin{tabular}{|c|c|c|c|c|c|c|c|c|c|c|}
\hline \multirow{2}{*}{$\begin{array}{l}\text { Taxonomic } \\
\text { group }\end{array}$} & \multirow[b]{2}{*}{$2-3$} & \multirow[b]{2}{*}{$7-8$} & \multirow[b]{2}{*}{$12-13$} & \multirow[b]{2}{*}{$16-17$} & \multicolumn{2}{|c|}{ Depth of sediment $(\mathrm{cm})$} & \multirow{2}{*}{$30-31$} & \multirow{2}{*}{\multicolumn{2}{|c|}{$36.5-37.541 .5-42.5$}} & \multirow[b]{2}{*}{$45-46$} \\
\hline & & & & & $20-21$ & $27-28$ & & & & \\
\hline Bryozoans & 0.6418 & 0.4030 & 0.2128 & 0.1521 & 0.00 & 0.00 & 0.00 & 0.00 & 0.00 & 0.00 \\
\hline Sponge spicules & 0.0450 & 0.0194 & 0.0333 & 0.0009 & 0.000126 & 0.000026 & 0.00 & 0.00 & 0.00 & 0.00 \\
\hline Polychaetes & 0.0603 & 0.0903 & 0.0509 & 0.0180 & 0.00 & 0.00 & 0.00 & 0.00 & 0.00 & 0.00 \\
\hline Ostrocods & 440.61 & 857.33 & 820.34 & 1112.65 & 73.23 & 0.00 & 0.00 & 0.00 & 0.00 & 0.00 \\
\hline Benthic foraminifera & 919.54 & 927.70 & 993.65 & 1338.87 & 108.59 & 0.00 & 0.00 & 0.00 & 0.00 & 0.00 \\
\hline Echinoderm spines & 38.31 & 95.97 & 23.11 & 13.85 & 0.00 & 0.00 & 0.00 & 0.00 & 0.00 & 0.00 \\
\hline Brachiopods & 86.21 & 115.16 & 86.66 & 96.95 & 0.00 & 0.00 & 0.00 & 0.00 & 0.00 & 0.00 \\
\hline Pteropods & 57.47 & 102.37 & 63.55 & 120.04 & 0.00 & 0.00 & 0.00 & 0.00 & 0.00 & 0.00 \\
\hline Planktonic foraminifera & 67.05 & 95.97 & 259.97 & 309.33 & 73.23 & 0.00 & 0.00 & 0.00 & 0.00 & 1.98 \\
\hline Radiolarians & 19.16 & 6.40 & 11.55 & 4.62 & 0.00 & 0.00 & 0.00 & 0.00 & 0.00 & 0.00 \\
\hline Gastropods & 0.00 & 19.19 & 11.55 & 23.08 & 0.00 & 0.00 & 0.00 & 0.00 & 0.00 & 0.00 \\
\hline Other taxa & 76.63 & 211.13 & 115.54 & 244.69 & 22.73 & 0.00 & 0.00 & 0.00 & 0.00 & 0.00 \\
\hline
\end{tabular}

Editorial responsibility: John Gray (Contributing Editor), Oslo, Norway
Submitted: October 10, 2006; Accepted: March 5, 2007

Proofs received from author(s): July 30, 2007 